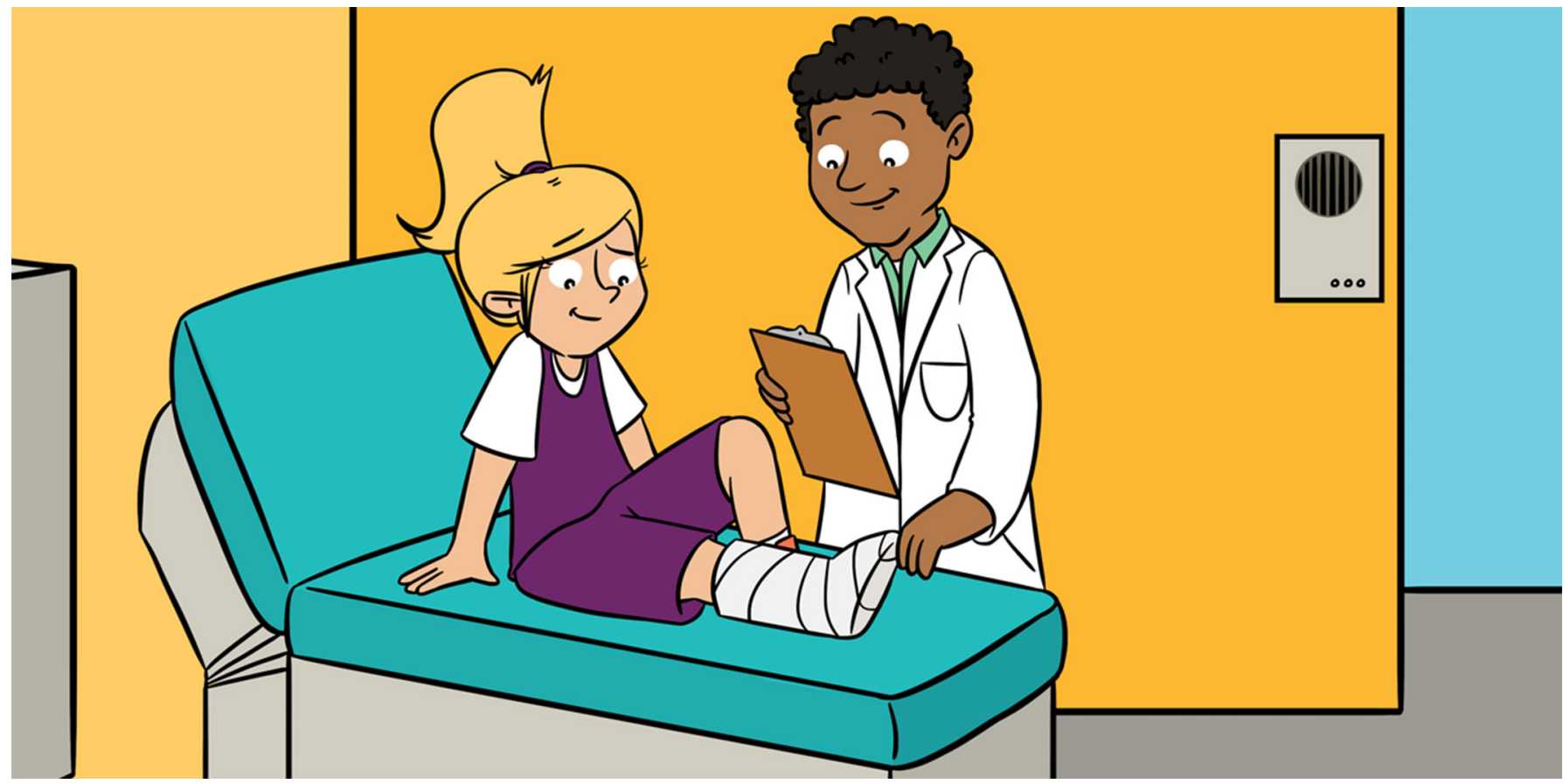

\title{
HOW DO BROKEN BONES HEAL?
}

\section{${ }^{1}$ Institute of Physical Chemistry, Polish Academy of Sciences, Warsaw, Poland \\ ${ }^{2}$ Gruca Orthopaedic and Trauma Teaching Hospital, Otwock, Poland \\ ${ }^{3}$ Radiotherapy Department, Military Institute of Medicine, Warsaw, Poland \\ ${ }^{4}$ Faculty of Chemistry, University of Warsaw, Warsaw, Poland}

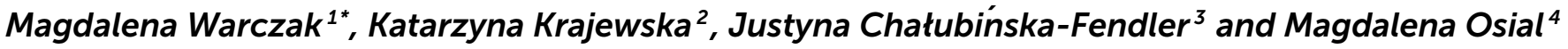

YOUNG REVIEWERS:

JULIA,

HARNOOR,

SRIJIA,

DHAANIYA,

MAI,

XIANGYU,

ROOPA,

SYBIL, AND

SARRANYA

AGES: $15-16$

hi 6 ANANEAH

AGE: 13
The human skeleton is truly amazing. It is a moving frame that protects soft tissues and organs, while simultaneously storing minerals and producing blood cells and immune cells. Bones also have an amazing ability to rebuild and repair themselves. There is no need to worry much if you break a bone because, with the support of your doctors and therapists, the bone should heal itself. Bones have a flexible structure that serves as the scaffolding for the minerals that create a strong and stable skeleton. Unfortunately, bone strength may decrease with age or due to food or hormonal deficiencies. When you experience pain, swelling, or bruising following a fall, you should go to the doctor to see if you have a bone fracture. But do not worry-remember that bones can repair themselves! Have you ever wondered how bone healing happens? You can find the answers in this article. 


\section{FUNCTIONS OF BONES}

Did you know that humans are born with 270 bones? However, during childhood and adolescence, some of them fuse together and, as a result, we have just 212 bones as adults. For example, newborn babies have unfused skull bones, making the head more flexible and easier to squeeze through the mother's birth canal. As the baby grows, the skull bones fuse together.

The main functions of the skeleton are to protect the body, give structure to the body, enable movement, and even enable hearing! Did you know that the smallest bones are located in the middle ear? They are responsible for enhancing the sounds that are transmitted to the inner ear. Meanwhile, the biggest bones are the femur bones in the legs. These bones are quite strong and support the entire body. The bones have other important functions, too. Bones may store and release minerals, such as calcium and phosphorus. They are important for keeping bones strong and hard. Calcium is an essential mineral not only for the bone formation but also for proper functioning of nerves, muscles and heart. Therefore, calcium is released from the bones in to the bloodstream when other part of body needs it.

Some bones contain red bone marrow, a soft, spongy tissue that produces white blood cells, which protect us from infection, red blood cells, which carry oxygen, and platelets, which help the blood to clot when there is an injury. What makes bones even more wonderful is that they can heal themselves. To understand this fascinating process, let us first look at what bones are made of.

\section{BONES FROM THE INSIDE}

Without even using a microscope, we can see that bones are

\section{CANCELLOUS BONE}

A spongy, porous, and light tissue inside the bone.

\section{COMPACT BONE}

An external layer of bone, much harder and dense than cancellous bone.

\section{PERIOSTEUM}

An outer coat of bone covering the compact bone.

\section{HYDROXYAPATITE}

A natural mineral that builds the bones and makes them harder composed of an inner, sponge-like tissue called cancellous bone, a dense, tough tissue called compact bone, and an outer coat called the periosteum (Figure 1). Lots of minerals are stored in the inner, spongy, cancellous bone, and that is also where bone marrow is located. Compact bone surrounds cancellous bone and is much harder and stronger. Cancellous bone gives bones most of their strength. The periosteum provides nourishment for the other parts of the bone, among other functions. The periosteum is full of nerves that transmit information about pain, which is why you feel pain when a bone is broken.

If we look closer, with a microscope, we can see that bones are made up of living cells and a structural framework between those cells, called a bone matrix, which is made of fibers and minerals. Bones contain a mineral called hydroxyapatite, which is made from calcium and phosphorus. Minerals make up $65-70 \%$ of bone mass. Minerals gives the bones their compressive strength, meaning that if you press on a 
Figure 1

Bones contain an inner spongy type of bone called cancellous bone, surrounded by a denser bone called compact bone. The compact bone is covered by an outer coat called the periosteum, which nourishes the bone and is full of nerves that can transmit pain signals if the bone is injured. In their centers, some bones contain red bone marrow, which produces red blood cells, white blood cells, and platelets.

\section{COLLAGEN}

A natural fiber that supports bone tissue and makes it more elastic.

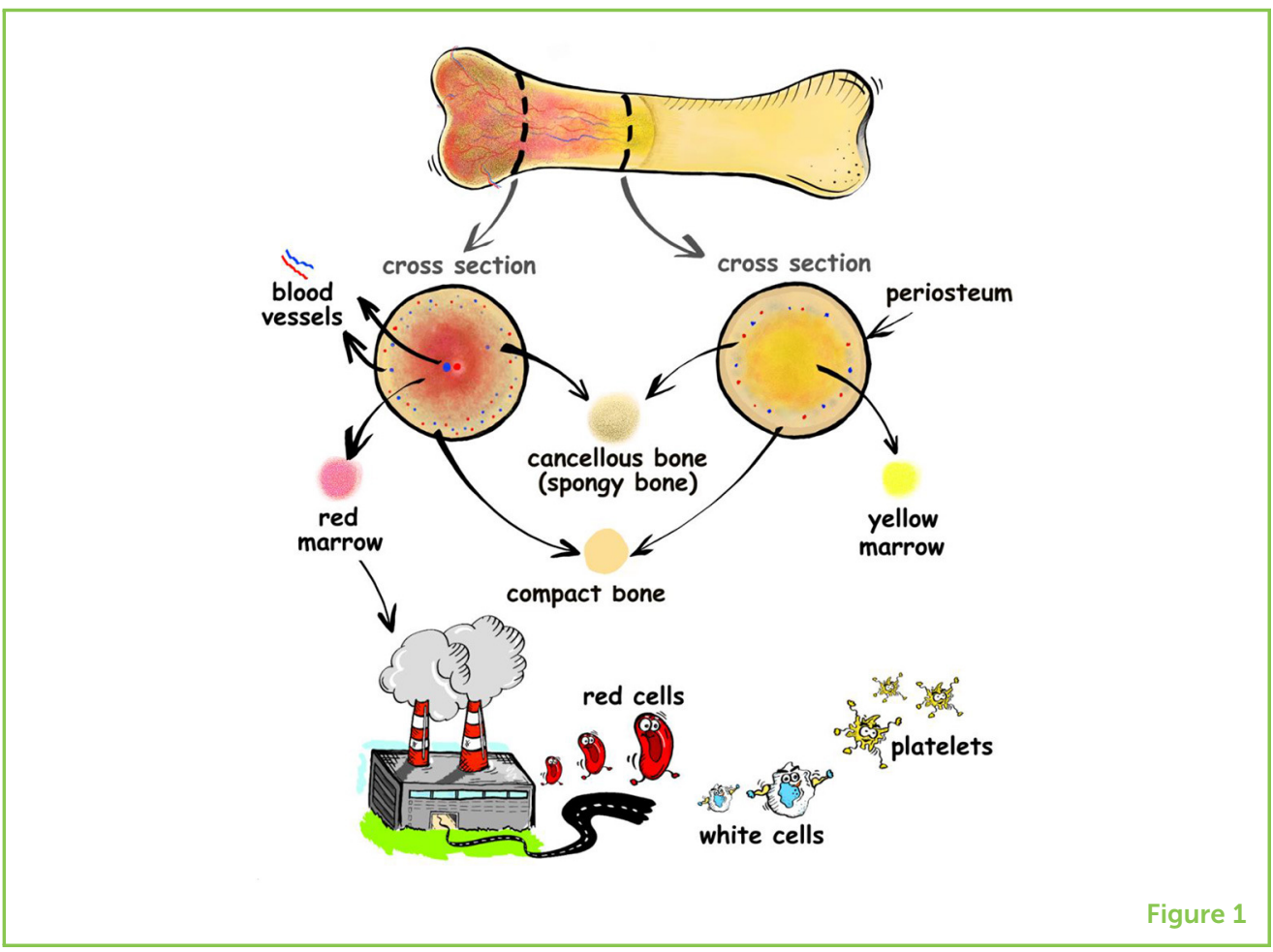

bone, it is resistant to breaking. Meanwhile, fibers make up the other $30-35 \%$ of bone [1]. These fibers are mostly collagen, which is made of three chains wound together. Fibers give the skeleton tensile strength, so when you pull on a bone, it will not be torn.

Bones also contain four types of specialized bone cells (Figure 2). Osteogenic cells are a type of stem cell, which means they can produce other types of cells. Osteogenic cells are the only bone cells that can divide and they are important because they produce all the other types of bone cells. Osteoblasts are responsible for building bones. They make bones strong by creating and placing a protein mixture on which hydroxyapatite builds up. Osteoblasts make up 5\% of all bone cells and are located mainly in growing bone regions at the bone surface. Osteocytes are the engineers and experienced builders. They make up about $90 \%$ of bone cells and are found in the bone matrix. They communicate with other cells and regulate osteoblasts' and osteoclasts' work to shape the bone. Thus, osteocytes are responsible for new bone growth and repair. Osteocytes are one of the longest-living cell types in the body-they can live for decades! Last, osteoclasts are like the cleaning staff that supports bones. They are responsible for removal of old bone when a bone needs repair.

\section{FOUR STEPS OF BONE HEALING}

Bone fractures happen quite often, particularly when we are young. They may be caused by sudden compression, such as the impact of 
Figure 2

There are four types of specialized bone cells that work together as a team to help repair bones after a fracture.

\section{HEMATOMA}

Describes the area in the body where blood is collected outside of the blood vessels.

\section{CALLUS}

A temporary network of fibers and cartilage formed during the repair phase of bone healing, replacing the hematoma, and linking together broken parts of bone.

\section{CARTILAGE}

A tough, flexible type of connective tissue occurring at the ends of bones, at the joints, and in other parts of the body, including the nose and ears.

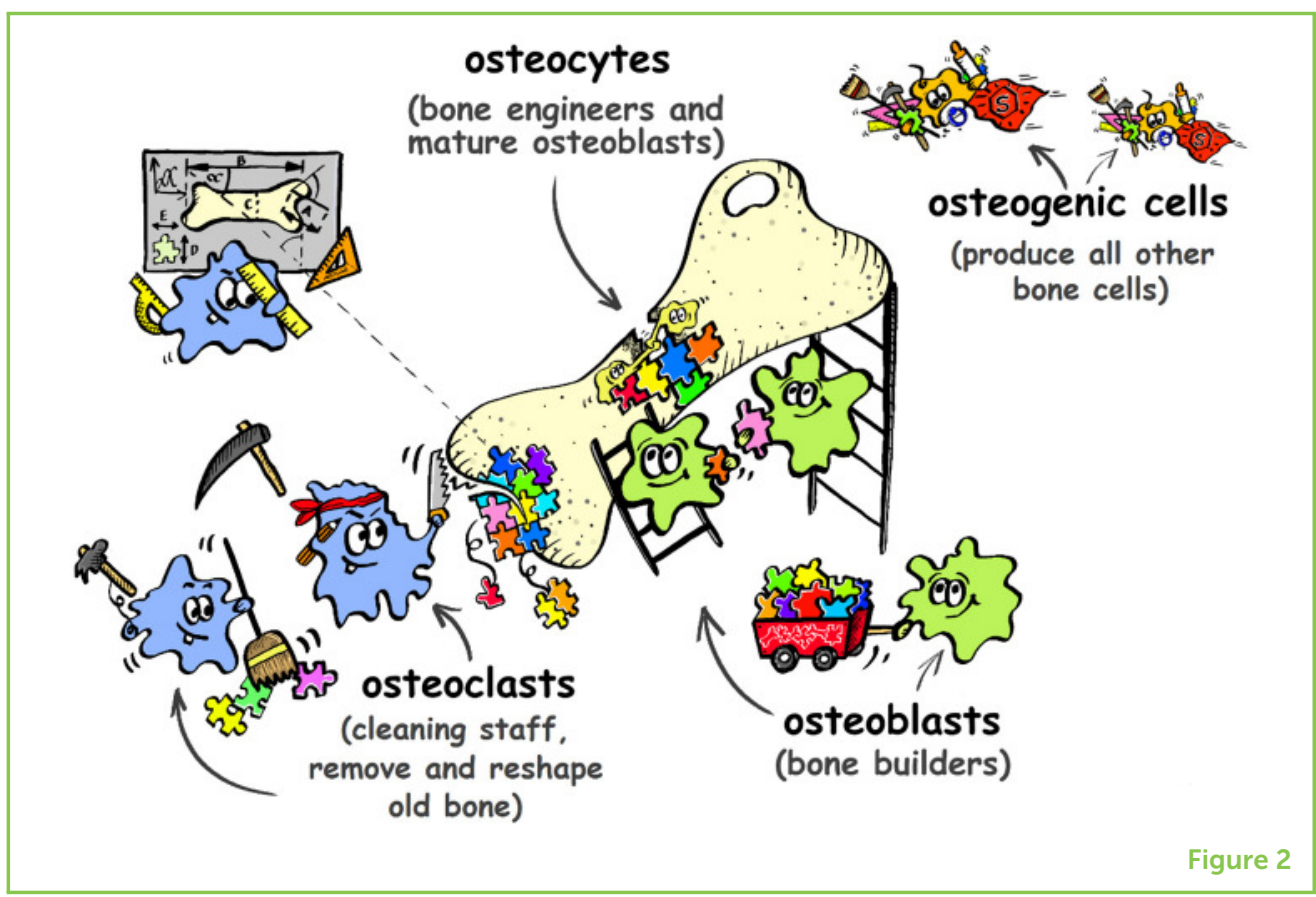

a swift fall. Breaking can split the bone into smaller pieces; it may be cracked, jagged, or shattered. Tiny pieces can be fused together by doctors or removed by surgery. Right after a bone fracture, the body sends out signals to start bone healing. These signals cause cellular and chemical reactions. You can imagine the process like a production line in a workshop full of specialists, where each one has a specific role. Bone healing is a four-step process consisting of inflammation, repair, new bone formation, and bone remodeling (Figure 3) [2].

\section{Step 1-Inflammation}

Did you know that pain is one of the first signs of a fracture? Swelling and bruising also occur in the injured area after an accident like a fall from a tree. The pain signal sent from a broken bone says, "Do not move; do not further injure the broken bone; stay still and calm." When a bone breaks, the blood vessels in the bone usually break too. Sometimes when the blood cells escape you can see a hematoma, which is the medical term for a bruise, when blood clots form after blood leaks into the area surrounding a bone fracture. We want this happen, because the clotting blood serves as the link between the fractured bone fragments, and acts as a template on which a temporary network of fibers and cartilage, called callus, is formed. Cartilage is a strong, gel-like, fibrous tissue made of specialized cells that produce collagen. The immune system starts the process of inflammation in the injured area. Other cells of the immune system are responsible for cleaning up the injury site and preparing the injured area for new bone formation. These cells remove the blood clots and other debris to allow healthy blood flow into the damaged area. After they finish their job, it is time for repair. 
Figure 3

Bone healing happens in four steps. First, inflammation occurs after the injury. Then the bone is induced to repair and is forming soft callus. At the third step the bone gets stronger and forms hard callus. At the last step, the new compact bone is formed and blood vessels regenerate.

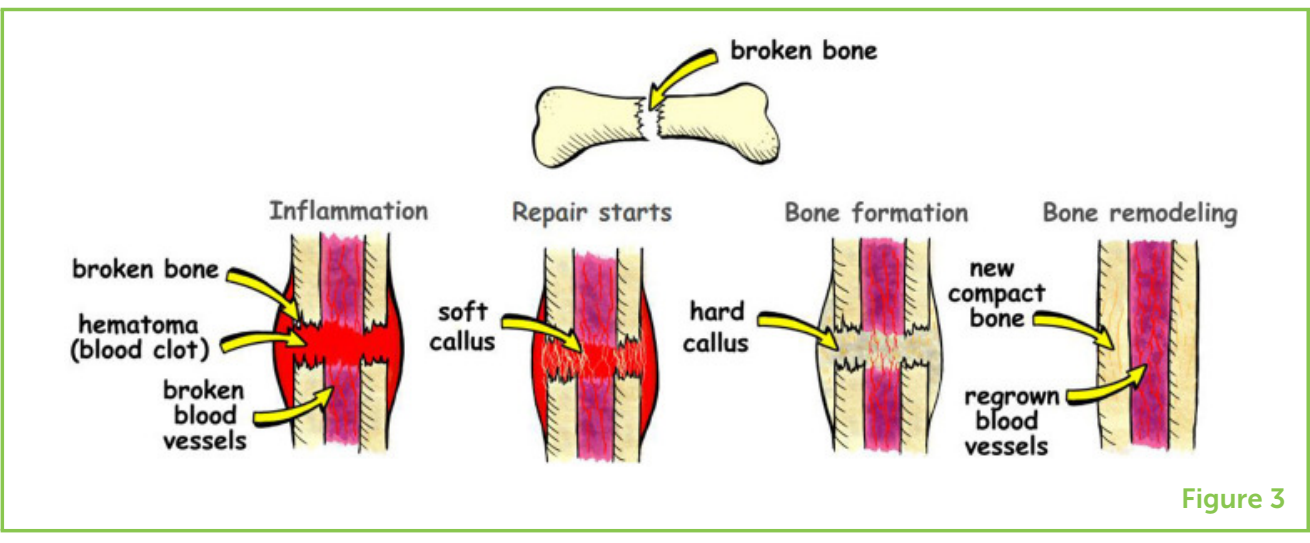

\section{Step 2-The Beginning of Repair}

This step mostly happens thanks to osteogenic cells. They start their work by forming osteoblasts and other cells responsible for producing fibers in the bone. The new bone starts to form when the hematoma is replaced by a soft callus, with new blood vessels inside. Fibers and cartilage are involved in the formation of this soft link between fragments of broken bone.

\section{Step 3-Bone Formation}

Several weeks after injury, thanks to osteoblasts and minerals, the soft, fibrous callus gets strengthen and turns into a hard cartilage callus, which is weaker than normal bone but better resistant to external forces.

\section{Step 4-Bone Remodeling}

The last stage involves the formation of new, strong bone. The hard callus is replaced and reshaped into new bone, which matches the original shape and size of the fractured bone. It is amazing that body remembers the initial shape and size of bones-this is not true for all organs. Osteoclasts and osteoblasts are amazing cleaners and architects, and they are responsible for bone sculpturing. These cells work for several months to complete their work and, when the healing is finished, the bone looks and works as if it were brand new.

\section{SUPPORTING BONE HEALTH}

Broken bones heal faster when we are young. The healing process depends on many factors, including bone density, which refers to the amount of minerals in the bone. When bone density is correct, the bone is healthy, while low bone density means that the bone is more porous and weaker. Cracks and fractures happen more easily in weak bones. Bone density increases during childhood and adolescence and is most intensive at age 11-13. Around 16, bone density stabilizes but remains active. A healthy bone density requires a proper diet, especially when you are growing. Remember to eat foods rich in calcium to 
"feed" your bones. Calcium is found in most dairy products, fish, and even in fruits and vegetables. Sometimes, calcium supplements are needed. Some other nutrients, such as vitamin D3, are required for proper immune system functioning and healthy bones. Vitamin $\mathrm{K}$ is necessary for blood clotting and bone healing, while magnesium and potassium help absorb calcium from the digestive system, so that it can be used by the rest of the body. If you do not supply your body with enough of these essential ingredients, your bones will become brittle and more prone to breaking.

And, of course, you should remember to exercise and be active. Did you know that bone density in athletes, especially those participating in high-impact sports, is significantly greater than in non-athletes? Regular sports activities are great for our bones because they increase bone density. So, do not just be a couch potato; stay active to grow your muscles and strengthen your bones [3]. But remember that some sports may lead to fractures, so choose your sports carefully and be sure to wear the proper protective gear. Protecting the bones is important, because the skeleton not only supports posture and protects the body, but it also produces blood cells and regulates mineral storage. If you do break a bone, do not worry! Bones have a very interesting and effective process of repairing themselves. Thanks to living cells, when a fracture happens, the natural healing process begins. Healing may seem like a complex process, but it is accomplished through the teamwork of many specialized cells, all of which know what to do and how to bring your broken bone back to its proper shape and function.

\section{REFERENCES}

1. Oryan, A., Monazzah, S., and Bigham-Sadegh, A. 2015. Bone injury and fracture healing biology. Biomed. Environ. Sci. 28:57-71. doi: 10.3967/bes2015.006

2. Canale, S. T., and Beaty, J. H. 2012. Campbell's Operative Orthopaedics. Vol. 3. Mosby, St. Louis: 2012, 2777-820.

3. Andreoli, A., Monteleone, M., Van Loan, M., Promenzio, L., Tarantino, U., De Lorenzo, A. 2001. Effects of different sports on bone density and muscle mass in highly trained athletes. Med. Sci. Sports Exerc. 33:507-11. doi: 10.1097/000057 68-200104000-00001

SUBMITTED: 01 July 2020; ACCEPTED: 13 August 2021;

PUBLISHED ONLINE: 08 September 2021.

EDITED BY: Jorge Galindo-Villegas, Nord University, Norway

CITATION: Warczak M, Krajewska K, Chałubińska-Fendler J and Osial M (2021) How Do Broken Bones Heal? Front. Young Minds 9:579201. doi: 10.3389/frym. 2021.579201 

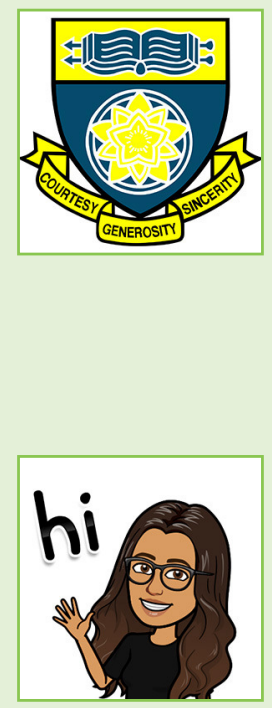

CONFLICT OF INTEREST: The authors declare that the research was conducted in the absence of any commercial or financial relationships that could be construed as a potential conflict of interest.

COPYRIGHT @ 2021 Warczak, Krajewska, Chałubinska-Fendler and Osial. This is an open-access article distributed under the terms of the Creative Commons Attribution License (CC BY). The use, distribution or reproduction in other forums is permitted, provided the original author(s) and the copyright owner(s) are credited and that the original publication in this journal is cited, in accordance with accepted academic practice. No use, distribution or reproduction is permitted which does not comply with these terms.

\section{YOUNG REVIEWERS}

JULIA, HARNOOR, SRIJIA, DHAANIYA, MAI, XIANGYU, ROOPA, SYBIL, AND SARRANYA, AGES: 15-16

We are a group of young inquisitive students with a keen interest in science. We love to gain new insights and perceive science with a critical eye. We develop a passion for the Sciences that goes beyond our curriculum and syllabus. We had a very enlightening experience as this reviewing process was something out of the ordinary for all of us! Together we are Julia, Harnoor, Srija, Dhaaniya, Mai, Xiangyu, Roopa, Sybil, and Sarranya.

\section{ANANEAH, AGE: 13}

I love thinking about science and know I want to be a cancer biologist when I grow up. I love animals and like to spend time with my dog, chickens, and rabbits. I enjoy music and can play the flute and piano. I also love singing. With my friends, I play basketball and soccer when I am free.

\section{AUTHORS}

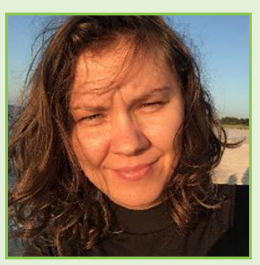

\section{MAGDALENA WARCZAK}

Magdalena Warczak is a scientist from the Institute of Physical Chemistry of the Polish Academy of Sciences. She conducts fundamental research aiming at chemical and electrochemical surface modifications of nanomaterials for potential biomedical (bone implants) and renewable energy system applications. She enjoys cycling, and books reading in her free time. mwarczak@ichf.edu.pl; *warczak24@wp.pl

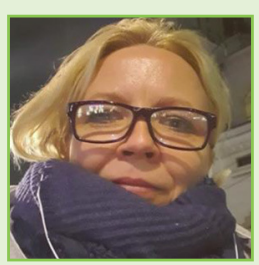

\section{KATARZYNA KRAJEWSKA}

Katarzyna Krajewska is a medical doctor aiming at fracture problems. She has just completed her residency in orthopedics in Gruca Orthopedic and Trauma Teaching Hospital in Otwock in Poland. She specializes in bone healing and in the interdisciplinary team supporting scientists in the implementation of new fracture treatment. Her passion is hiking and playing the piano. 


\section{JUSTYNA CHAŁUBINSKA-FENDLER}

Justyna Chałubinska-Fendler is a medical doctor in the Military Institute of Medicine in Warsaw. She made her Ph.D. in radiation oncology in the Medical University of Lodz. She used to work on many interdisciplinary projects including biostatistics. She enjoys horse riding and traveling.

\section{MAGDALENA OSIAL}

Magdalena Osial is a scientist from the University of Warsaw. Her research focuses on the development of treatments for various diseases. She is a chemist and collaborates with scientists from the various fields working on different interdisciplinary projects. Her passion is science popularization, so when she is not in the laboratory she enjoys science workshops for kids. She also enjoys hiking, drawing, dying, board games, and old-school PC games. 